\title{
What factors of satisfaction and motivation are affecting the development of the academic career in Portuguese higher education institutions?*
}

\author{
Maria de Lourdes Machado-Taylor** \\ Virgílio Meira Soares*** \\ José Brites Ferreira**** \\ Odília Maria Rocha Gouveia*****
}

\begin{abstract}
Summary: 1 . Introduction; 2 . Theorethical background: the state of the art; 3 . Brief overview of the academic profession in the Portuguese higher education institutions; 4. Instruments and sampling; 5. Final thoughts.
\end{abstract}

SumÁRIo: I. Introdução; 2. A base teórica: o nível mais elevado; 3. Breve panorama da profissão acadêmica nas instituições portuguesas de ensino superior; 4. Instrumentos e amostragem; 5. Considerações finais.

KEYWords: higher education; satisfaction; motivation; academic staff.

Palavras-chave: ensino superior; satisfação; motivação; acadêmicos.

An important constituent group and a key resource of higher education institutions (HEIs) is the faculty or academic staff. The centrality of the faculty role makes it a

\footnotetext{
* Article received in Out. 2010 and accepted in Dec. 2010.

** Doutoramento em Ciências Empresariais. Investigadora do Centro de Investigação de Políticas do Ensino Superior (Cipes) e Instituto Politécnico de Bragança (IPB). Endereço: Rua 1o de Dezembro, 399 - 4450-227, Matosinhos, Portugal. E-mail: lmachado@cipes.up.pt.

*** Doutoramento em engenharia química (química termodinâmica). Professor e Investigador da Universidade de Lisboa (UL) e do Cipes. Endereço: Alameda da Universidade, 1600, Lisboa, Portugl. E-mail: vmsoares@fc.ul.pt.

$* * * *$ Doutoramento em ciências da educação. Professor e investigador do Instituto Politécnico de Leiria (IPL) e do Cipes. Endereço: Rua 1 de Dezembro, 399 - 4450-227 Matosinhos, Portugal. E-mail: brites@esel.ipleiria.pt.

$* * * * *$ Licenciatura em sociologia. Assistente de Investigação do Cipes. Endereço: Rua 1을 de Dezembro, 399 - 4450-227 Matosinhos, Portugal.E-mail: odilia@cipes.up.pt.
} 
primary sculptor of institutional culture and has implications for the quality of the institution and therefore has a major role in achieving the objectives of the institution. Demand for academic staff in higher education has been increasing and may be expected to continue to increase. Moreover the performance of academic staff as teachers and researchers determines much of the student satisfaction and has an impact on student learning. There are many factors that serve to undermine the commitment of academics to their institutions and careers. Job satisfaction is important in revitalizing staff motivation and in keeping their enthusiasm alive. Well motivated academic staff can, with appropriate support, build a national and international reputation for themselves and the institution in the professional areas, in research and in publishing. This paper aims to identify the issues and their impacts on academic staff job satisfaction and motivation within Portuguese higher education institutions reporting an ongoing study financed by the European Union through the Portuguese Foundation for Science and Technology.

Que fatores de satisfação e motivação estão afetando o desenvolvimento da carreira acadêmica em instituições de ensino superior em Portugal?

Os docentes ou pessoal acadêmico são um importante grupo constituinte e recursochave das instituições de ensino superior (IES). A centralidade do papel do docente faz dele um escultor fundamental da cultura institucional, com implicações na qualidade da instituição e, consequentemente, na prossecução dos objetivos da instituição. A procura de docentes no ensino superior tem vindo a aumentar e é expectável que continue a crescer. Além disso, o desempenho do pessoal docente (grupo no qual se incluem docentes e investigadores) determina em grande medida a satisfação dos estudantes e tem impacto na sua aprendizagem. Existe um vasto conjunto de fatores que contribuem para minar o compromisso do pessoal docente com suas instituições e carreiras. A satisfação no trabalho é importante na revitalização da motivação do pessoal e em manter vivo seu entusiasmo. Pessoal docente bem motivado pode, com o apoio adequado, construir uma reputação nacional e internacional para si e para a instituição nas áreas profissionais, na investigação e na publicação. Este artigo visa identificar tópicos com impacto na satisfação profissional e motivação do pessoal docente das instituições de ensino superior em Portugal, descrevendo um estudo em curso financiado pela União Europeia, através da Fundação para a Ciência e a Tecnologia.

\section{Introduction}

Today's higher education institution (HEI) is an extremely complex social organization. One must examine a multitude of factors and their numerous interactions in order to even approach an understanding of its functions. One cannot minimize the confounding effects the human factor introduces to so- 
cial organizations. Here, we will pay attention to a particular group - the academic staff - as a key resource within higher education institutions and his major role in achieving the objectives of the institution.

Demand for academic staff in higher education has been increasing and may be expected to continue to increase. The centrality of the faculty role makes it a primary sculptor of institutional culture. According to Altbach and Chait (2001, cited in Ssesanga and Garrett, 2005), the work of academics is influenced by global trends such as accountability, massification, deteriorating financial support and managerial controls. So, we assist to the rapid change of the academic workplace and to the necessity to manage the tensions within the academic profession. Moreover, for Altbach (2003), with the era of mass higher education the conditions of academic work have deteriorated everywhere.

The performance of academic staff as teachers and researchers determines much of the student satisfaction and has an impact on student learning and thus the contribution of the higher education institutions (HEIs) to society. Thus satisfaction and motivation of the academic staff assumes importance. Oversimplified and naïve explanations of job satisfaction abound in all sectors of the workforce. Most typical is the mistaken belief that pay incentives alone will create effective levels of motivation and thus, overall job satisfaction. Previous research indicates that dissatisfaction stems from inadequate and non-competitive salaries and further lack of job satisfaction due to non-monetary reasons. There are intrinsic variables related to personal growth and development, and extrinsic factors associated with security in the work environment. There is also ample and somewhat obvious evidence that job satisfaction is related to employee motivation.

\section{Theorethical background: the state of the art}

Job satisfaction is multi-dimensional with both intrinsic and extrinsic qualities. The former include ability, achievement, advancement, compensation, co-workers, creativity, independence, moral values, social service, social status and working conditions. The latter involve authority, policies and practices, recognition, responsibility, security and variety (Weiss et al., 1967). According to Herzberg (1966), intrinsic factors relate to job satisfaction when present but not to dissatisfaction when absent. The extrinsic factors are associated with job dissatisfaction when absent but not with satisfaction when present. 
As noted by Altbach (2003:1) "Conditions of work and levels of remuneration are inadequate, involvement in institutional governance is limited, and the autonomy to build both an academic career and academic programs is constrained. The sad fact [is] [...] the conditions of academic work have deteriorated." Research shows that the youngest and oldest employees tend to be the most satisfied (Clark, Oswald and Warr, 1996), women are typically more satisfied than men, all other things being equal (Clark, 1997), the higher one's earnings, the lower their satisfaction, and the higher the level of education, the lower the job satisfaction (Clark, Oswald and Warr, 1996). They also found that expectations can become a major factor in job satisfaction, and they are generally much higher with more education. With higher, unrealistic job expectations can come increased disappointment. Ward and Sloane (2000) showed the need to study absolute salary and level relative to expectations. Parenthetically, Hartog and Oosterbeck (1998) found that overall satisfaction with life is lower for the highly educated. Winstead et al. (1995) stressed that a friendly workplace has more relevance than the role of managers and workers. Lacy and Sheehan (1997) in a study in eight countries concluded that relationships with colleagues, job security and the impact of context elements such as working climate and behavior of managers have the greatest predictability of satisfaction. Evans (1997) found leadership and professional orientations as factors influencing satisfaction in the UK. Verhaegen (2005) found in 12 countries that the importance of remuneration is surpassed by academic autonomy, research opportunities, and professional and personal development. Many models explain job satisfaction (Rice et al., 1991), but none focus uniquely on academic staff in higher education. The typical dimensions of job satisfaction are management, colleagues, other work groups, job satisfaction, physical environment and salary and other material benefits (Küskü, 2001).

Two models are appropriate here. Nyquist, Hitchcock and Teherani (2000) propose one. See figure 1.

L. Hagedorn (2000), for example, wrote about faculty job satisfaction using the "Conceptual Framework of Faculty Job Satisfaction", being her mission to sort and categorize the factors that contribute to job satisfaction. This model hypothesizes two types of constructs that interact and affect job satisfaction. These constructs are triggers and mediators. A trigger is a significant life event that may be either related or unrelated to the job. A mediator is a variable or situation that influences or moderates the relationships between other variables or situations producing an interaction effect. The mediators represent situations, developments and extenuating circumstances that pro- 
vide the context in which job satisfaction must be considered. The conceptual model presented by L. Hagedorn (2000) is composed by six triggers and three types of mediators, forming a framework in which faculty job satisfaction may be scrutinized. An adaptation of Hagedorn, (2000) illustrates another model. See table 1.

\section{Figure 1}

\section{Conceptual Model \# 1 of Academic Staff Job Satisfaction}

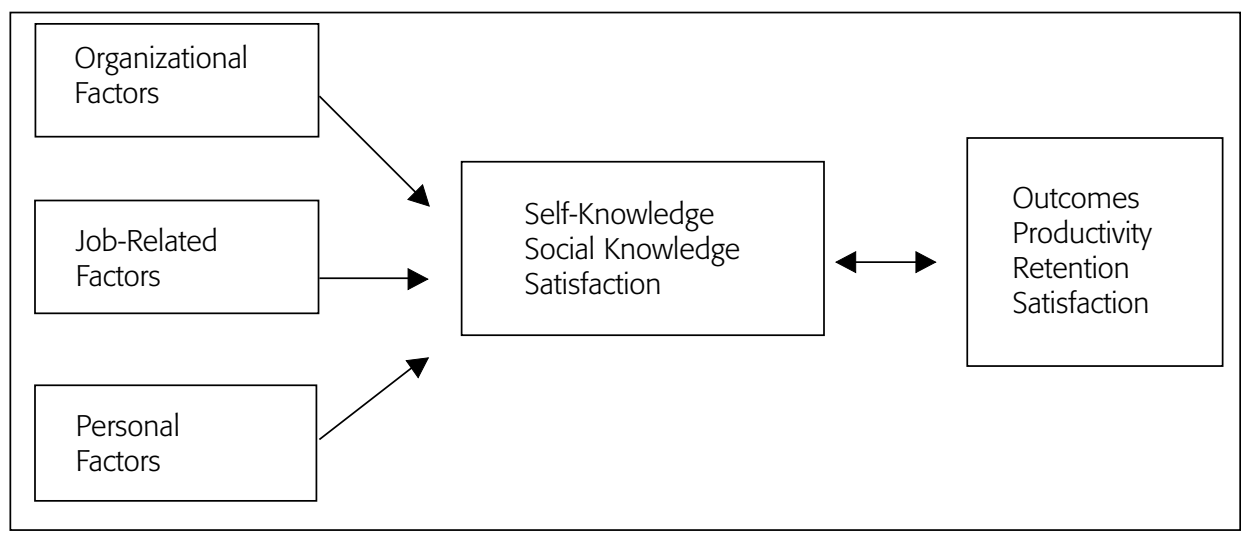

Adapted from: Nyquist, Hitchcock and Teherani (2000).

Table 1

Conceptual Model \#2 of Academic Staff Job Satisfaction

\begin{tabular}{|llll|}
\hline & Mediators & & Triggers \\
\hline Achievement & Gender & Collegial Relations & Life Stage \\
Recognition & Ethnicity & Student Quality & Personal/Family \\
Work itself & Institutional Type & Administration & Rank/Tenure \\
Responsibility & Acad. Discipline & Climate/Culture & New Institution \\
Advancement & & & Perceived Justice \\
Salary & & & Emotional State \\
& & & \\
\hline
\end{tabular}

Adapted from: Hagedon (2000).

General survey research identifies universal factors, but not in the perspective of higher education (Ambrose, Huston and Norman, 2005). A powerful factor affecting job satisfaction is motivation. Employee motivation is important to job performance and institutional well-being. Effort and ability 
are additive in creating job performance. This is why individuals with lesser natural talent or professional expertise can sometimes outperform their more gifted colleagues. HEIs must not only hire the most capable individuals but also use strategies to inspire them to do their best (Taylor et al., 2007). Motivated individuals have direction and persistence of action, even in the face of difficulties and challenges (Mitchell, 1982). As noted by Mullins (1999), there are four common denominators from theories that characterize motivation as 1) an individual phenomenon, 2) intentional and under the individual's control, 3) multifaceted involving arousal to act and choice of behavior, and 4) intended to predict behavior. There are four general categories of motivation theory that span half a century - content theories, process theories, situational models and role theories. Content theory examines fulfillment of needs and attainment of intrinsic and extrinsic factors. See Maslow (1970), Alderfer (1972) and Herzberg (1966). Process theories attempt to identify the relationships among variables that make up motivation and the subsequent actions used to influence behavior. See Vroom (1964) and Adams (1965). Situational models look at the interaction between the individual, the task and organizational characteristics. See Quarstein, McAfee and Glassman (1992), and Glisson and Durick (1988). Role theories examine the interplay of roles, positions and individual characteristics, and are most recognized by Biddle's two theories of role conflict and role ambiguity (Goff, 2004). Dinham and Scott (1998:362-363) state that, "Satisfaction and motivation are inextricably linked through the influence each has on the other." Herzberg et al. (1959) stressed the need to strengthen motivators in order to engender career satisfaction. Dinham and Scott (1998:362-363) pointed out that career satisfaction is connected to need fulfillment, as conceptualized by Maslow (1970) and Alderfer (1972). Evans (1999) suggests motivation is a model of the job fulfillment process. Many scales exist to measure employee satisfaction (Tang and Talpade, 1999; Goff, 2004). They tend to reflect theoretical positions, and thus are modified to fit the parameters of the study at hand (Küskü, 2001). Some are designed for higher education (see Küskü, 2001; Verhaegen, 2005), however an instrument will be developed specifically for this project.

\section{Brief overview of the academic profession in the Portuguese higher education institutions}

In Portugal, academic careers differ substantially between the public and private sub-systems. Too little is known about the private system. Most of the follo- 
wing is about academic careers in public institutions. However, it is important to note that the public system enrolls $75 \%$ of all students and constitutes $70 \%$ of all teaching staff in Portuguese higher education (Oces, 2005a, 2005b).

The legal framework of academic careers is quite different in public and private institutions. The government defines the size of the teaching staff and creates the rules for career advancement within public institutions. The academics of public institutions are civil servants as opposed to those that work at private institutions. Within private institutions, there are no established regulations about the academic profession. Furthermore, the size of the body of academics, career advancements and remunerations are defined by the institutional decision makers. The academic university and polytechnic staff differ in positions, career advancements and remunerations. Mobility between the sub-systems is possible; however it is not very common. The rigidity of policies and regulations, and the lack of a legal framework supporting any kind of mobility inhibit such moves.

The growth of the public system in the '90s meant a large expansion of teaching staff, particularly in the newly born public polytechnic sub-system. For instance in the polytechnic sub-system, the coordinator professors grew in some institutions by as much as 1,600\% between 1993 and 2004. For this same period at the public universities, there was an increase of academic staff of from $61 \%$ to $385 \%$, with one relatively young university reaching $3,350 \%$ (Oces, 2005a, 2005b). Data from Oces (2005c) reveals that only 59\% of the teaching staff (December, 2004) are regular permanent professors with $23 \%$ being full professors and $36 \%$ associate professors. The number of permanent professors is much lower for polytechnics at $6 \%$.

One can emphasize the importance of the University as a subsystem of higher education that employs more than half of all professors in the country. Public Higher Education in Portugal employed in 2008, a total of 22923 professors, 14742 wok at universities and 8181 in the polytechnic institutes. Thus, the proportion of professors exercising their professional activity in a university is much higher than the proportion of professors working at the polytechnic institutes ( $64.3 \%$ and $35.7 \%$ respectively).

It is observed that the proportion of male professors is higher than the proportion of female professors, both in the universities and in the polytechnics. Indeed, in the universities the proportion of men is $59.1 \%$ and the proportion of female professors is $40.9 \%$. The weight of male professors in the Polytechnics is $55.5 \%$ and the proportion of female professors is of $44,5 \%$. The imbalance between men and women is more significant in universities than in the polytechnics (DGES, 2008). 


\section{Instruments and sampling}

An eclectic quantitative and qualitative approach will be adopted for this project in order to embrace the full spectrum of theoretical orientations and perspectives. Several methodologies will be utilized to gather the data and information needed for this study: 1) quantitative survey data gathering, 2) qualitative interview data gathering and 3) qualitative document examination. The first assignment will be to develop the survey instrument. The sample will be quite large (the universe of academic staff). Further stratifications will be made based on academic staff sub-groups (professor, researcher, part-time, full-time, etc.), geographic location (North, Centre and South) and institutional type (public-private, university-polytechnic, etc.). All quantitative data collected will be placed in a comprehensive database reflecting a national sample of academic staff members. The database and its subsequent analyses will be performed with the Statistical Package for the Social Sciences (SPSS). The survey will yield quantitative data. The team will also develop an interview protocol to provide supplemental, qualitative information. The protocol will provide structure to the interviewing process to maintain administrative consistency. For this model to have utility, the mediating constructs must be translated into more meaningful operational components that are measurable and quantifiable to the extent possible. This will be especially evident from the data gathered from the questionnaire that will be administered anonymously to the academic staff of participating institutions. Qualitative data from the interviewing process will be examined and interpreted by multiple members of the research team in order to ensure inter-rater reliability. The task will be to recategorize the data based on the narratives received. Thus the coders will essentially identify the common themes emerging from the interviews.

The qualitative and quantitative data and information gathered will be brought together and analyzed to provide the following broad-based insights:

- Identify factors and their interactions affecting job satisfaction and motivation of academic staff;

v Analyze how job satisfaction and motivation differ among academic staff sub-groups;

v Determine the relationships between satisfaction, motivation, allegiance (institutional and disciplinary). 


\section{Final thoughts}

The research team will generate significant scholarship to share with the academic community in professional venues and through publications, and also attempt to provide meaningful information to institutions that can be applied to practical situations. These resources will be intended to bring the findings of the study across the bridge from theory to practice for the HEIs that will hopefully benefit from this. Armed with empirically derived information and practical suggestions, the HEIs will be better equipped to confront the challenges of academic staff job satisfaction and promote a positive work environment.

Higher education institutions are now in a time of globalization, traversed by profound contradictions, uncertainties and doubts, not only due to a lack of resources or quality of resources but which are also conceptual in nature and concern the extension and amendment of its mission (Burbules and Torres, 2004; Morgado and Ferreira, 2006), with consequences also in the "job" of professors (Hargreaves, 1998, 2003; Tardif and Lassardi, 2008). In this context, the study of academic staff job satisfaction and motivation to carry out their professional activities becomes crucial, especially as higher education is being traversed by multiple changes, including the teaching profession, as is the case of Portugal. The realization of this project will provide a diverse range of information on multiple dimensions of the faculty job in higher education, in particular dimensions of satisfaction and motivation, as well as dimensions of the academic career and the professional context in which it is exercised.

\section{References}

ADAMS, J.S. Inequity in social exchange. Adv. Exp. Soc. Psychol., v. 62, p. 335-343, 1965.

ALDERFER, C. Existence, relatedness, and growth: human needs in organizational settings. New York: Free Press, 1972.

ALTBACH, P. (Ed.) The decline of the guru: the academic profession in developing and middle-income countries. New York: Palgrave/MacMillan, 2003.

AMBROSE, S.; HUSTON, T; NORMAN, M. A qualitative method for assessing faculty satisfaction. Research in Higher Educ., v. 46, n. 7, p. 803-830, 2005.

BURBULES, N.C.; TORRES, C.A. Globalização e educação: uma introdução. In: 
BURBULES, N.C.; TORRES, C.A. (Org.). Globalização e educação: perspectivas críticas. São Paulo: Artmed, 2004.

CLARK, A.E. Job satisfaction and gender: why are women so happy at work? Labour Economics, v. 4, n. 4, p. 341-372, 1997.

CLARK, A.; OSWALD, A.; WARR, P. Is job satisfaction U-shaped in age? Journal of Occupational and Organizational Psychology, v. 69, p. 57-81, 1996.

DGES — INDEZ 2008 Direcção-Geral do Ensino Superior, 2008.

DINHAM, S.; SCOTT, C. A three domain model of teacher and school executive career satisfaction. Journal of Educational Administration, v. 36, n. 4, p. 362-378, 1998.

EVANS, L. Managing to motivate: a guide for school teachers. London: Cassell, 1999.

EVANS, L. Understanding teacher morale and job satisfaction. Teaching and Teacher Education, v. 13, n. 8, p. 831-845, 1997.

GLISSON, C.V.; DURICK, M. Predictors of job satisfaction and organizational commitment in human service organizations. Administrative Quarterly, v. 33, n. 1, p. 61-68, 1988.

GOFF, D.G. Job satisfaction of community college academic deans. PhD Thesis. — University of South Florida, Suth Florida, 2004.

HAGEDORN, L. S. Conceptualizing faculty job satisfaction: components, theories, and outcomes. New Directions for Institutional Research, n. 105, XXVII (1), p. 5-20, 2000.

HARGREAVES, A. Os professores em tempos de mudança: o trabalho dos professores na idade pósmoderna. Alfragide: Mc Graw-Hill, 1998.

. O Ensino na sociedade do conhecimento: a educação na era da insegurança. Porto: Porto Editora, 2003.

HARTOG, J.; OOSTERBECK, H. Health, wealth and happiness: why pursue a higher education? Economics of Educ. Rev., v. 17, p. 245-256, 1998.

HERZBERG, F. Work and the Nature of Man. New York: Thomas Y. Crowell Publishers, 1966.

HERZBERG, F.; MAUSNER, B.; SNYDERMAN, B. The motivation to work. New York: John Wiley \& Sons, 1959.

KÜSKÜ, F. Dimensions of employee satisfaction: A State University example. METU Studies in Development, v. 28, n. 2, p. 399-430, 2001. 
LACY, F.J.; SHEEHAN, B.A. Job satisfaction among academic staff: an international perspective. Higher Education, v. 34, n. 3, p. 305-322, 1997.

MASLOW, A. Motivation and personality. 2nd ed. New York: Harper \& Row, 1970.

MITCHELL, T. Motivation: new directions for theory, research and practice. Academy of Management Rev., v. 7, n. 1, p. 80-88, 1982.

MORGADO, J.C.; FERREIRA, J.B. Globalização e autonomia: desafios, compromissos e incongruências. In: MOREIRA, A.F.; PACHECO, J.A. (Ed.), Globalização e educação. Porto: Porto Editora, 2006.

MULLINS, L. Management and organizational behavior. 5th ed. London: Financial Times/Pittman Publishing, 1999.

NYQUIST, J.G.; HITCHCOCK, M.A.; TEHERANI, A. Faculty satisfaction in academic medicine. New Directions for Institutional Research, v. 27, n. 1, p. 33-43, 2000.

OCES - Observatório da Ciência e do Ensino Superior. Ensino superior público: pessoal docente e rácio aluno/docente ETI. Lisboa: Oces, 2005c.

. Evolução por categoria do pessoal docente do ensino superior politécnico público: 1993 a 2004. Lisboa: Oces, 2005a.

. Evolução por categoria do pessoal docente do ensino superior universitário público: 1993 a 2004. Lisboa: Oces, 2005b.

QUARSTEIN, V.A.; MCAFEE, R.B.; GLASSMAN, M. The situational occurrences theory of job satisfaction. Human Relations, v. 45, n. 8, p. 859-873, 1992.

RICE, R.; GENTILE, D.; MCFARLIN, D. Facet importance and job satisfaction. Journal of Applied Psychology, v. 76, n. 1, p. 31-39, 1991.

SSESANGA, K.; GARRETT, R.M. Job satisfaction of university academics: perspectives from Uganda. Higher Education, v. 50, n. 1, p. 33-56, 2005.

TANG, T.; TALPADE, M. Sex differences in satisfaction with pay and co-workers: faculty and staff at a public institution. Public Personnel Management, v. 28, n. 3, p. 345-349, 1999.

TARDIF, M.; LASSARDI, C.L. (Org.). O ofício de professor: história, perspectivas e desafios internacionais. Petrópolis: Editora Vozes, 2008.

TAYLOR, J.S. et al. Strategic enrollment management: improving student satisfaction and success in Portugal. Higher Education Management and Policy, v. 20, n. 1, p. 120-137, 2007.

VERHAEGEN, P. Academic talent: quo vadis? Recruitment and retention of faculty in European business schools. Journal of Management Development, v. 24, n. 9, p. 807-818, 2005. 
VROOM, V.H. Work and motivation. Oxford, England: Wiley, 1964.

WARD, M.E.; SLOANE, P. J. Non-pecuniary advantages versus pecuniary disadvantages: job satisfaction among male and female academics in scottish universities. Scottish Journal of Political Economy, v. 47, n. 3, p. 273-303, 2000.

WEISS, D. et al. Manual for the Minnesota Satisfaction Questionnaire. Minneapolis, MN: The University of Minnesota Press, 1967.

WINSTEAD, B. et al. The quality of friendships at work and job satisfaction. Journal of Social and Personal Relationships, v. 12, n. 2, p. 199-215, 1995. 